\title{
GEOCHEMISTRY OF THE AMSAGA AREA ORTHOGNEISSES (ARCHEAN REGUIBAT RISE, MAURITANIA)
}

\author{
ALAIN POTREL*
}

\begin{abstract}
Geochemical data (major, trace) obtained on the orthogneisses which formed the basement of the Amsaga area (Archean Reguibat Rise, West African Craton) demonstrate: 1) that these gneisses define a calc-alkaline trend of trondhjemitic affinity; 2) the existence of at least two different types of migmatitic orthogneisses in the Amsaga; 3) a perturbation of composition of these orthogneisses during the Archean granulitic event and Proterozoic
\end{abstract} hydrothermal event (s) which affected the Amsaga.

Keywords: Major, Trace, REE, Archean Reguibat Rise, West African Craton.

Resumo GEOQUÍMICA DOS ORTHOGNAISSES DA REGIÃO DO AMSAGA (DORSAL REGUIBAT ARQUEANA; MAURITANIA). Dados geoquímicos (elementos maiores e traço) obtidos nos ortognaisses que formam o embasamento da região do Amsaga (Dorsal Reguibat, Craton do Oeste da África) mostram: 1) que os gnaisses formam um trend calcio-alcalino com afinidade trondhjemítica; 2) a presença de pelo menos dois tipos diferentes de ortognaisses migmatíticos naquela área; 3) perturbações da composição química destes gnaisses durante o metamorfísmo granulítico arqueano e o metamorfismo hidrothermal proterozóico que afetaram a região do Amsaga.

Palavras-chaves : Maiores, Traço, REE, Dorsal Reguibat arqueana, Craton do Oeste da África.

INTRODUCTION The West African craton (Fig. I) is mainly composed of two shields, the Man Shield in the South and the Reguibat Rise in the North, separated by the sedimentary (Upper Proterozoic to Paleozoic) Taoudeni basin. These two shields are formed of both Archean and Proterozoic formations. The Archean part of these two domains, and in particular the Archean Reguibat Rise, have been only poorly studied. The present work represents the first geochemical study of the orthogneiss which forms the basement of the Archean Reguibat Rise. The studied area (the Amsaga area in the southwestern Reguibat Rise; Fig. 1) consists of a typical high grade terrain (Windley 1986) comprised of supracrustal series intruded by charnockitic bodies and migmatitic orthogneisses. These migmatitic orthogneisses exhibit field characteristics of archean TTG (eg. Arth \& Hanson 1975). The present study aims to: 1) characterize the chemical composition of these migmatitic orthogneisses which where until now thought to be homogeneous based on field relationships (e.g. Barrère 1967, Auvray et ai. 1992a et b, Bronner 1992); 2) compare the chemical composition of the migmatitic orthogneisses and charnockite.

GEOLOGICAL SETTING The Amsaga area (Fig. 1) is mainly composed of major blocks separated by vertical mylonitic zones. The northern zone consists of supracrustal units (metapelites and metagraywackes) intruded by charnockitic bodies. The most important are the Snine Kembo and Bou Rhzama plutons. The central and eastern zones are formed of migmatitic orthogneisses overlain by volcanosedimentary belts. The supracrustal series of the north are also exposed in the south-eastern part of the area, but are not associated with any charnockitic pluton in this sector.

The whole area suffered a high-grade (granulite and migmatite) metamorphism event following a clockwise P-T path from a peak located near $800 \pm 50{ }^{\circ} \mathrm{C}$ and $5 \pm 1 \mathrm{~kb}$ (Potrel 1994). The retrograde evolution began with a near isothermal decompression and stopped rapidly $\left(\sim 650-700{ }^{\circ} \mathrm{C}\right)$, but in lithologies located near the main shear zones, the granulitic paragenesis are replaced by low grade assemblages (Bt II \pm Muse $\pm \mathrm{Ep} \pm$ $\mathrm{Spn} \pm \mathrm{Zo} \pm \mathrm{Cal} \pm \mathrm{Chi}$ ). This low grade recrystallization grew statically and was not associated with a deformation event, so all the structures observed in the field could be linked to the granulitic event. Two syn-or late-tectonic but post-granulite plutons, the Touijenjert granite and the Iguilid gabbro, intruded the granulitic and migmatitic series at the end of the geological evolution. Both are affected by low grade recrystallization.

A sample of ortho-migmatitic gneiss has been dated by $\mathrm{U}-\mathrm{Pb}$ SHRIMP and yielded an age of ca. 3.45 - 3.5 Ga. This age, in agreement with the Nd model age of the sample (3.64 $\mathrm{Ga}$ ), marks the first crustal formation event documented in the area (Potrel et al. 1996). A second crust formation event had been dated at ca. 3.0 Ga by dating (U-Pb SHRIMP and Sm-Nd isochron) the charnockitic pluton of Snine Kembo (Potrel 1994, Potrel et al, submitted). The migmatitic orthogneisses studied in the present work are for the moment poorly dated. The only available age obtained on those gneisses is a single zircon evaporation date of $2836 \pm 14$ Ma (Potrel 1994). Furthermore, these gneisses exhibit a scattering in their Nd model ages (between ca. 2.8 and $3.2 \mathrm{Ga}$ ) and show rather parallel $\varepsilon N d$ versus time evolution lines which could indicate the presence of various magmatic bodies with various ages and/or sources (Potrel et al., submitted). The two late-tectonic and post-granulite plutons were dated at ca. $2.7 \mathrm{Ga}$ : the Touijenjert granite yielded a U-Pb SHRIMP age of $2726 \pm 7$ $\mathrm{Ma}$ and the Iguilid gabbro a Sm-Nd mineral isochron age of $2706 \pm 54 \mathrm{Ma}$ (Potrel 1994, Potrel et al., submitted). This age, in agreement with a single zircon evaporation age of ca. 2.74 Ga obtained on the granulitic Guelb el Azib gabbro (Auvray et al. 1992a, Potrel 1994), is interpreted as the age of the granulite event. The Touijenjert granite yielded Nd model ages ranging between 3.1 and $3.2 \mathrm{Ga}$, so its emplacement marked the onset of crustal reworking in the area (Potrel 1994, Potrel et al., submitted). No crustal formation event or magma emplacement younger than $2.7 \mathrm{Ga}$ has been documented in the area, but resetting ages obtained in $\mathrm{Rb}-\mathrm{Sr}$ system at ca 2.5 and $2.3 \mathrm{Ga}$ indicate that the area was thermally affected during the Proterozoic evolution of the craton (Potrel 1994). This Proterozoic thermal event (s) is interpreted as having been responsible for the low grade recrystallizations observed in the samples.

* Géosciences Rennes (U.P.R. C.N.R.S.4661) - Rennes Cedex, França. 




Figure 1 - Simplified geological map of the Amsaga area (after Barrère 1967), sample location and location of the area in the West African Craton.

Figura l - Mapa simplificado da região do Amsaga (modificado de Barrère 1967), localização das amostras e localização da região dentro do Craton do Oeste da África. 
SAMPLES AND METHODOLOGY Ten samples of the charnockitic pluton of Snine Kembo and fourteen orthomigmatitic gneisses (location Fig. 1) have been studied. The paragenesis of the Snine Kembo massif is typical of granulite fades conditions $(\mathrm{Qtz}+\mathrm{PI}+\mathrm{Kfs}-\mathrm{t}-\mathrm{B} \mathrm{t}+\mathrm{Opx} \pm \mathrm{Cpx})$. As this massif is located far from the mylonitic shear zones, the samples are not affected by the low grade recrystallization and the granulitic paragenesis is generally well preserved. The primary paragenesis of orthomigmatitic samples (Qtz + Pig + $\mathrm{Kfs}+\mathrm{Bt} \pm \mathrm{Hb}$ ) shows retrograde metamorphism such as breakdown to low grade phases: chlorite, calcite, prehnite, sericite, titanite, epidote (Fe-epidote, zoisite, clinozoisite). The most retrograde samples have not been reported here.

Major and trace element contents (except Rare Earth Elements, REE) were analyzed by X-ray fluorescence. REE contents were determined in two ways: by ICPMS in the Department of Geology Southampton (U.K.) by J.A. Barrat (in that case $\mathrm{U}$ and $\mathrm{Hf}$ contents were also determined) and by isotopic dilution using a CAMECA TSN 206 single collector mass spectrometer in the University of Rennes.
RESULTS Major elements (Table 1) In a normative classification diagram (O'Connor 1965 modified by Barker 1979; Fig. 2a) samples define three distinct groups: the charnockites plot in the tonalite field and the ortho-migmatitic gneisses plot both in the trondjhemite (Tdj) and granodiorite groups. Two samples of migmatitic gneisses plot also in the tonalitic field, one close to the Tdj field. Here after the two main groups of trondhejemitic and granodioritic compositions will be distinguished in discution and figures. Show on the A/CNK versus $\mathrm{SiO}_{2}$ diagram (Fig. 2b) all the analyzed samples plot along the calc-alkaline trend. The analyses scatter in the K-Na-Ca diagram (Barker and Arth 1976; Fig. 2c) but plot close to the trondjhemitic trend.

Traces elements (Table 2) In a $\mathrm{Y}$ versus $\mathrm{Nb}$ diagram (Pearce et al. 1984; Fig. 3), samples plot in the Arc and Syn-collision granite field. But it may be seen in this diagram that three samples (AG154, AG158 and AG161) have anomalous low $\mathrm{Y}$ contents (less than $1 \mathrm{ppm}$ ). In a $\mathrm{Y}+\mathrm{Nb}$ versus $\mathrm{Rb}$ diagram (Pearce et al. 1984; Fig 4), all samples plot in the Island Arc granite field.
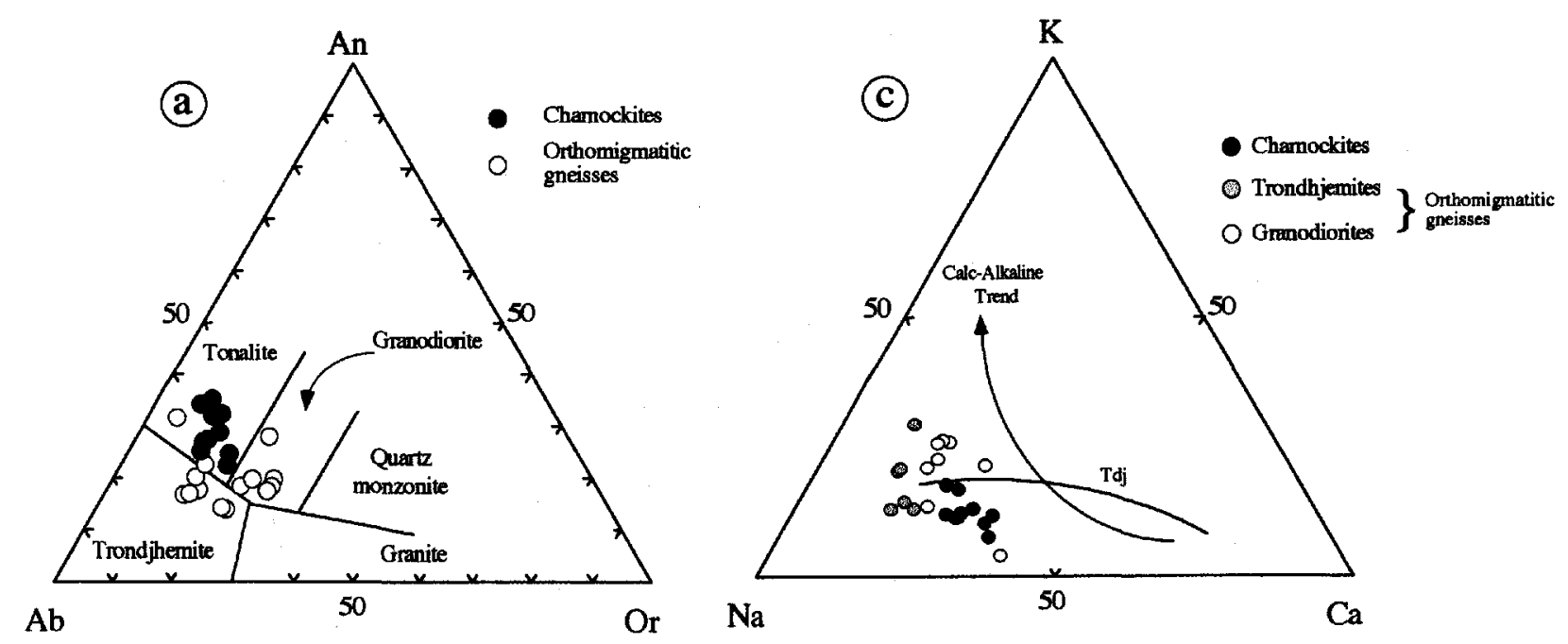

(b)

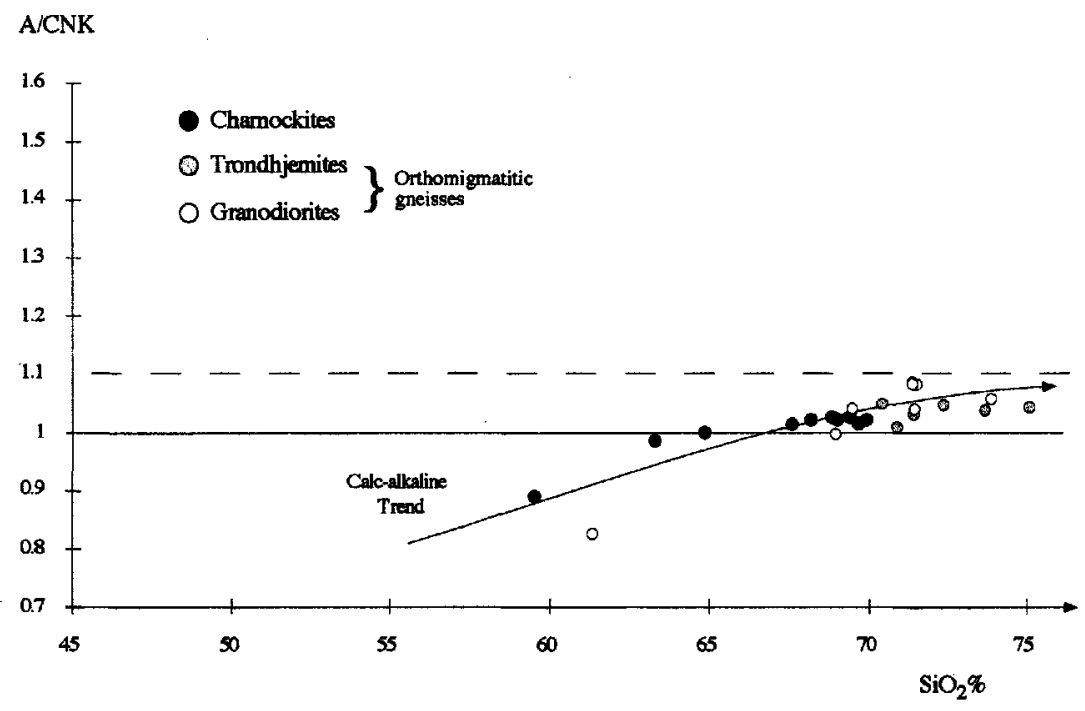

Figure 2 - (a) - Normative An-Ab-Or classification (O'Connor 1965 modified by Broker 1979) of the Amsaga ortho gneisses.(b) - A/CNK vs. $\mathrm{SiO}_{2}$ diagram showing the calc-alkaline character of Amsaga orthogneisses. (c) -K-Na-Ca diagram showing the trondhjemitic affinity of the Amsaga calc-alkaline trend.

Figura 2 - (a) - Classificação normativa An-Ab-Or (O'Connor 1965, modificado por Barker 1979) dos ortognaisses de Amsaga. (b) - Diagrama A/CNK vs. SiO 2 monstrando o caráter calcio-alcalino dos ortognaisses de Amsaga. (c) -Diagrama K-Na-Ca monstrando a afinidade trondhjemítica do trend calcio-alcalino de Amsaga. 
Table 1 - Major element compositions for the Amsaga orthogneisses in wt \%. Tabela 1 - Composição química (elementos maiores) dos ortognaisses do Amsaga, \% em peso.

\begin{tabular}{|c|c|c|c|c|c|c|c|c|c|c|c|c|c|c|}
\hline & Nature & Samples & $\mathrm{SiO}_{2}$ & $\mathrm{Al}_{2} \mathrm{O}_{3}$ & $\mathrm{Fe}_{2} \mathrm{O}_{3}$ & $\mathrm{MnO}$ & $\mathrm{MgO}$ & $\mathrm{CaO}$ & $\mathrm{Na} 2 \mathrm{O}$ & $\mathrm{K}_{2} \mathrm{O}$ & $\mathrm{TiO}_{2}$ & $\mathrm{P}_{2} \mathrm{O}_{3}$ & LOI & Total \\
\hline \multirow{14}{*}{$\begin{array}{c}\text { Orthomigmatitic } \\
\text { gneisses }\end{array}$} & \multirow{6}{*}{ Trondhjemites } & AG154 & 70.42 & 16.17 & 2.02 & 0.02 & 0.59 & 2.83 & 5.23 & 1.54 & 0.26 & 0.06 & 0.74 & 99.88 \\
\hline & & AG235 & 70.90 & 15.65 & 2.00 & 0.02 & 0.43 & 2.44 & 5.69 & 1.55 & 0.26 & 0.05 & 0.41 & 99.40 \\
\hline & & AG162 & 71.37 & 15.45 & 2.17 & 0.03 & 0.42 & 2.52 & 5.24 & 1.68 & 0.23 & 0.08 & 0.53 & 99.72 \\
\hline & & AG 159 & 72.35 & 15.26 & 1.51 & 0.02 & 0.23 & 2.01 & 5.06 & 2.45 & 0.13 & 0.04 & 0.42 & 99.48 \\
\hline & & AG158 & 73.65 & 14.58 & 1.36 & 0.01 & $0: 15$ & 1.92 & 4.91 & 2.27 & 0.11 & 0.03 & 0.31 & 99.30 \\
\hline & & AG161 & 75.10 & 14.67 & 0.38 & 0.01 & 0.04 & 1.72 & 4.46 & 3.35 & 0.03 & 0.01 & 0.25 & 100.02 \\
\hline & \multirow{6}{*}{ Granodionites } & AG242 & 68.97 & 15.67 & 3.59 & 0.06 & 1.17 & $\mathbf{3 . 8 0}$ & 3.79 & 2.39 & 0.41 & 0.13 & 0.73 & 100.71 \\
\hline & & $A G 239$ & 71.39 & 14.29 & 3.35 & 0.04 & 0.62 & 2.29 & 4.10 & 2.12 & 0.29 & 0.08 & 0.64 & 99.21 \\
\hline & & AG200 & 71.41 & 14.52 & 2.77 & 0.03 & 0.58 & 2.25 & 3.90 & 2.65 & 0.26 & 0.09 & 0.82 & 99.28 \\
\hline & & AG240 & 71.46 & 15.21 & 2.04 & 0.03 & 0.64 & 2.65 & 4.31 & 2.52 & 0.23 & 0.06 & 0.41 & 99.56 \\
\hline & & AG199 & 71.52 & 14.27 & 3.37 & 0.02 & 0.74 & 2.41 & 3.64 & 2.62 & 0.28 & 0.07 & 0.54 & 99.48 \\
\hline & & AG8 & 72.11 & 14.56 & 2.78 & 0.03 & 0.76 & 2.37 & 3.93 & 2.79 & 0.24 & 0.06 & 0.56 & 100.19 \\
\hline & \multirow[t]{2}{*}{ Tonalites } & AG245 & 69.52 & 15.28 & 3.04 & 0.05 & 0.86 & 2.99 & 4.66 & 1.46 & 0.35 & 0.10 & 0.79 & 99.10 \\
\hline & & AG217 & 61.34 & 15.78 & 7.62 & 0.11 & 2.28 & 5.90 & 4.77 & 0.50 & 0.84 & 0.15 & 0.64 & 99.93 \\
\hline \multirow{10}{*}{ Chamockites } & \multirow{10}{*}{ Tonalites } & AG125 & 69.08 & 15.53 & 3.8 & 0.05 & 1.2 & 4.21 & 3.91 & 1.06 & 0.4 & 0.13 & 0.38 & 99.75 \\
\hline & & AG126 & 64.91 & 16.97 & 5.43 & 0.03 & 1.54 & 4.34 & 4.51 & 1.53 & 0.57 & 0.13 & 0.4 & 100.36 \\
\hline & & AGl27 & 67.64 & 16.93 & 3.34 & 0.06 & 0.98 & 4.09 & 4.69 & 1.41 & 0.39 & 0.1 & 0.22 & 99.85 \\
\hline & & AG128 & 63.3 & 17.54 & 5.51 & 0.08 & 1.79 & 5.12 & 4.58 & 0.88 & 0.62 & 0.14 & 0.24 & 99.80 \\
\hline & & AG129 & 69.42 & 15.33 & 3.64 & 0.05 & 0.98 & 3.64 & 4.29 & 1.19 & 0.38 & 0.08 & 0.22 & 99.22 \\
\hline & & AG132 & 59.55 & 17.29 & 7.46 & 0.1 & 2.98 & 6.17 & 4.32 & 1.04 & 0.67 & 0.13 & -0.01 & 99.70 \\
\hline & & AG167 & 68.18 & 16.48 & 3.25 & 0.06 & 1.02 & 3.71 & 4.79 & 1.39 & 0.29 & 0.08 & 0.3 & 99.55 \\
\hline & & AG166 & 68.86 & 16.63 & 3.06 & 0.03 & 1.04 & 3.93 & 4.67 & 1.29 & 0.33 & 0.07 & 0.39 & 100.30 \\
\hline & & AG168 & 69.97 & 15.6 & 2.66 & 0.04 & 0.9 & 3.22 & 4.44 & 1.96 & 0.32 & 0.06 & 0.65 & 99.82 \\
\hline & & AG169 & 69.73 & 16.03 & 2.83 & 0.04 & 0.95 & 3.59 & 4.39 & 1.91 & 0.29 & 0.06 & 0.48 & 100.30 \\
\hline
\end{tabular}

Reported in a spidergram normalized to the chondrites (Fig. 5) all the samples show a negative Ti anomaly. The charnockites are highly depleted in Th and $U$ and have (to a lesser extent) a negative anomaly in $\mathrm{Rb}$. They show a rather flat pattern in $\mathrm{Sr}$ and positives anomalies in $\mathrm{Ba}$ and $\mathrm{Zr}$. They are depleted in Y. The Tdj have a negative Th anomaly and are highly depleted in $\mathrm{Y}$. They have positive $\mathrm{B}$ a, K, Sr and $\mathrm{Zr}$ anomalies. The granodiorite patterns are more variable as samples AG 242 and the tonalite AG 217 have different patterns than the other ones. They all exhibit negative $\mathrm{Sr}$ and $\mathrm{P}$ anomalies and also a sligthly negative $\mathrm{Nb}$ anomaly (this is less visible for sample AG 242 as it is strongly depleted in $U$ and $\mathrm{K}$, but its $\mathrm{Nb}$ content is the same as the other samples). All but AG 242 have negative $\mathrm{Ba}$ and positive $\mathrm{K}$, Th and $\mathrm{U}$ anomalies. They have also a positive Rb anomaly, except the tonalite AG 217 which has a strong negative anomaly.

As the entire area has undergone a granulitic facies metamorphism, the depletion in $\mathrm{K}, \mathrm{Rb}, \mathrm{Th}$ and $\mathrm{U}$ in the charnockites and Tdj could be linked to this event (Tarney \& Windley 1977, Weaver et al. 1978), but the $\mathrm{K} / \mathrm{Rb}$ ratios of the samples, if they are high (between 334 and 1167 for the charnockite and 376 and 846 for the Tdj; Tab. 2), remain lower than the classical ratios of depleted granulites (1000; Heier 1973). The $\mathrm{Rb} / \mathrm{Sr}$ ratios of the samples (Tab. 2) reflect the different behavior of these two elements in the distinct groups, with a low ratio for the charnockites and Tdj (between 0.03 and 0.18 and 0.06 and 0.1 respectively) and a higher one for the granodiorites (between 0.22 and 1.42). Sample AG 217 has $\mathrm{a} \mathrm{Rb} / \mathrm{Sr}$ ratio of 0.03 , which reflects its depletion in $\mathrm{Rb}$.

Rare Earth elements. The three groups of rock separated by major element contents also shown distinct REE patterns and contents (Fig. 6; Tab. 2). The Tdj show highly fractionated patterns $\left([\mathrm{La} / \mathrm{Yb}]_{\mathrm{N}}\right.$ between 37.04 and 67.61$)$ with positive or no Eu anomalies $\left(\mathrm{Eu} / \mathrm{Eu}^{*}\right.$ between 1 and 2.02). Furthermore, their REE contents are low ( $\Sigma$ REE between $\approx 40$ and 65$)$. The charnockites exhibit more variable REE patterns, less fractionated than those of the $\mathrm{Tdj}\left([\mathrm{La} / \mathrm{Yb}]_{\mathrm{N}}\right.$ between 8.99 and $27.37)$ with also a slightly positive or no Eu anomaly $\left(\mathrm{Eu} / \mathrm{Eu}^{*}\right.$ between 0.9 and 1.2). Their total REE contents overlap with the range of concentration of the Tdj samples ( $\sum$ REE between $\approx 54$ and 91). The granodiorites show the most distinct patterns, with a rather flat fractionation $([\mathrm{La} / \mathrm{Yb}] \mathrm{N}$ between 12.73 and 25.27), a negative Eu anomaly ( $\mathrm{Eu} / \mathrm{Eu}^{*}$ between 0.62 and 0.85 ) and a higher total REE content (EREE between $\approx 119$ and 156). Sample AG 217 of tonalitic composition shows REE content and pattern closer to that of the granodiorites, with a rather flat pattern $([\mathrm{La} / \mathrm{Yb}] \mathrm{N}$ of 6.64$)$, a slightly negative $\mathrm{Eu}$ anomaly $\left(\mathrm{Eu} / \mathrm{Eu}^{*}=0.92\right)$ and a total REE content of 100 . Furthermore, the REE contents and negative Eu anomaly of the granodiorites and samples AG 217 appears to accompany increasing $\mathrm{SiO}_{2}$.

INTERPRETATION The major element content of the Amsaga orthogneisses indicate clearly the presence of three petrologic groups in the area: charnockites of tonalitic composition and migmatitic orthogneisses of Tdj and granodioritic compositions (Fig. 2a). Variation diagrams indicate that the Amsaga orhtogneisses belong to a calc-alkaline trend with trondjemitic affinity (Fig. $2 b$ and c). This is in agreement with the island arc granite nature of the samples (Fig. 3 and 4). This kind of composition is particularly common in Archean granitoids (eg. Collerson \& Bridgwater 1979, Tarney et al. 1979, Windley 1986).

The trace element compositions of the gneisses are more perturbed due to the effect of the metamorphism and magmatic differentiation. Their negative $\mathrm{Ti}$ anomaly and the positive $\mathrm{Ba}$ and $\mathrm{Sr}$ anomalies of the charnockites and Tdj are in agreement with the Island Arc nature of the magma (eg. Gill 1981, Thompson et al. 1984). The fact that the granodiorites exhibit negative anomalies in $\mathrm{Ba}, \mathrm{Sr}$ and $\mathrm{P}$ can be linked to fractiona- 
Table 2 - Trace element compositions for the Amsaga orthogneisses, in ppm.

Note: For REE contents: \# signify isotopic dilution method; * signify ICP-MS analyses.

Tabela 2 - Composição química (elementos traço) dos ortognaisses do Amsaga em ppm.

Nota: Para as REE: \# significa análise por diluição isotópica; * significa análise por ICP-MS.

\begin{tabular}{|c|c|c|c|c|c|c|c|c|c|c|c|c|c|c|}
\hline & Nature & Samples & $\mathrm{Pb}$ & $\mathrm{Sr}$ & $\mathbf{R b}$ & $\mathrm{Ba}$ & $\mathrm{Zr}$ & Th & $\mathrm{Nb}$ & $\mathrm{Y}$ & $\mathbf{U}$ & Hf & $\mathrm{K} / \mathrm{Rb}$ & $\mathrm{Rb} / \mathrm{Sr}$ \\
\hline \multirow{14}{*}{$\begin{array}{l}\text { Migmatitic } \\
\text { Gneisses }\end{array}$} & \multirow{6}{*}{ Trondhjemites } & AG154 & 8 & 518 & 33 & 985 & 121 & 2 & 6 & $<1$ & - & - & 555 & 0.06 \\
\hline & & AG235 & 5 & 499 & 49 & 621 & 134 & 4 & 9 & 2 & $\cdot$ & - & 376 & 0.10 \\
\hline & & AG162 & 10 & 545 & 30 & 1026 & 158 & 4 & 6 & 2 & - & - & 667 & 0.06 \\
\hline & & AG159 & 11 & 343 & 35 & 1324 & 95 & $<1$ & 5 & 4 & - & - & 776 & 0.10 \\
\hline & & AG158 & 11 & 438 & 38 & 1351 & 106 & 3 & 4 & $<1$ & - & - & 768 & 0.09 \\
\hline & & AG161 & 11 & 453 & 47 & 1353 & 46 & $<1$ & 4 & $<1$ & - & - & 846 & 0.10 \\
\hline & \multirow{6}{*}{ Granodiorites } & AG242 & 7 & 342 & 77 & 1015 & 139 & 5 & 9 & 14 & 0.58 & 2.52 & 371 & 0.23 \\
\hline & & AG239 & 32 & 114 & 162 & 610 & 165 & 38 & 10 & 15 & - & - & 159 & 1.42 \\
\hline & & AG200 & 28 & 176 & 111 & 853 & 169 & 34 & 9 & 15 & - & - & 290 & 0.63 \\
\hline & & AG240 & 8 & 309 & 69 & 875 & 97 & 8 & 6 & 3 & - & - & 437 & 0.22 \\
\hline & & AG199 & 38 & 125 & 129 & 650 & 165 & 35 & 10 & 16 & - & - & 246 & 1.03 \\
\hline & & AG8 & 31 & 150 & 148 & 749 & 155 & 36 & 9 & 11 & 10 & 5.08 & 226 & 0.99 \\
\hline & \multirow[t]{2}{*}{ Tonalites } & AG245 & 14 & 249 & 61 & 334 & 151 & 10 & 8 & 8 & 2.86 & 3.45 & 289 & 0.24 \\
\hline & & AG217 & 6 & 281 & 8 & 195 & 140 & 5 & 9 & 20 & - & - & 751 & 0.03 \\
\hline \multirow{10}{*}{ Charnockites } & \multirow{10}{*}{ Tonalites } & AG125 & 3 & 248 & 24 & 644 & 163 & $<1$ & 6 & 5 & - & - & 532 & 0.10 \\
\hline & & AG126 & 6 & 260 & 35 & 705 & 154 & $<1$ & 11 & 11 & 0.19 & 0.86 & 520 & 0.13 \\
\hline & & AG127 & 6 & 323 & 26 & 704 & 138 & $<1$ & 7 & 6 & - & - & 645 & 0.08 \\
\hline & & AG128 & 6 & 300 & 9 & 322 & 179 & $<1$ & 9 & 8 & 0.27 & 2.28 & 1167 & 0.03 \\
\hline & & AG129 & 6 & 236 & 43 & 606 & 143 & 3 & 8 & 8 & 0.73 & 2.53 & 334 & 0.18 \\
\hline & & AG132 & 4 & 268 & 17 & 467 & 100 & $<1$ & 10 & 12 & - & - & 729 & 0.06 \\
\hline & & AG167 & 6 & 367 & 26 & 643 & 125 & $<1$ & 6 & 4 & - & - & 638 & 0.07 \\
\hline & & AG166 & 9 & 331 & 23 & 581 & 126 & $<1$ & 6 & 2 & 0.40 & 1.83 & 665 & 0.07 \\
\hline & & AGI68 & 7 & 264 & 26 & 940 & 136 & $<1$ & 6 & 4 & - & - & 902 & 0.10 \\
\hline & & AG169 & 8 & 306 & 32 & 914 & 130 & $<1$ & 7 & 4 & - & - & 710 & 0.10 \\
\hline
\end{tabular}

\begin{tabular}{|c|c|c|c|c|c|c|c|c|c|c|c|c|c|c|c|}
\hline & Nature & Samples & $\mathbf{L a}$ & $\mathrm{Ce}$ & $\mathrm{Nd}$ & Sm & Eu & Gd & Dy & $\mathrm{Er}$ & $\mathrm{Yb}$ & Lu & $\mathrm{La} / \mathrm{Y}$ & SREE & $\mathrm{Eu} / \mathrm{E}$ \\
\hline \multirow{8}{*}{$\begin{array}{l}\text { Migmatitic } \\
\text { Gneisses }\end{array}$} & \multirow{3}{*}{ Trondhjemites } & AG235\# & 12.34 & 28.21 & 9.66 & 1.58 & 0.46 & 1.27 & 0.87 & 0.32 & 0.22 & - & 33.99 & 54.93 & 1.00 \\
\hline & & AG162\# & 18.43 & 31.60 & 10.64 & 1.61 & 0.58 & 0.96 & 0.63 & 0.33 & 0.18 & - & 62.05 & 64.96 & 1.44 \\
\hline & & AG158\# & 10.65 & 20.01 & 6.34 & 1.01 & 0.51 & 0.60 & 0.32 & 0.14 & 0.11 & 0.02 & 58.68 & 39.71 & 2.02 \\
\hline & \multirow{3}{*}{ Granodiorites } & AG242* & 29.11 & 52.42 & 21.52 & 4.57 & 1.17 & 3.98 & 3.02 & 1.59 & 1.51 & 0.24 & 11.68 & 119.13 & 0.85 \\
\hline & & AG199\# & 33.15 & 59.01 & 19.84 & 3.29 & 0.65 & 3.04 & 2.51 & 1.35 & 1.21 & 0.19 & 16.60 & 124.24 & 0.63 \\
\hline & & AG8* & 42.48 & 72.77 & 25.25 & 4.68 & 0.90 & 4.24 & 2.67 & 1.40 & 1.11 & 0.16 & 23.19 & 155.66 & 0.62 \\
\hline & \multirow[t]{2}{*}{ Tonalites } & AG245* & 30.63 & 55.44 & 21.16 & 4.19 & 0.79 & 3.45 & 2.07 & 1.31 & 1.00 & 0.18 & 18.56 & 120.22 & 0.64 \\
\hline & & AG217\# & 21.22 & 44.35 & 17.72 & 3.74 & 1.12 & 3.80 & 3.69 & 2.19 & 2.11 & 0.33 & 6.10 & 100.27 & 0.92 \\
\hline \multirow{5}{*}{ Charnockites } & \multirow{5}{*}{ Tonalites } & AG126* & 20.35 & 37.69 & 17.89 & 4.17 & 1.13 & 3.58 & 2.56 & 1.5 & 1.43 & 0.2 & 8.62 & 90.54 & 0.90 \\
\hline & & AG128* & 14.7 & 28.12 & 13.99 & 3.45 & 1.14 & 3.09 & 2.12 & 1.26 & 1.08 & 0.17 & 8.25 & 69.12 & 1.08 \\
\hline & & $\mathrm{AG} 129^{*}$ & 20.93 & 36.06 & 14.74 & 3.05 & 1.08 & 2.54 & 1.8 & 1.09 & 1.03 & 0.2 & 12.32 & 82.52 & 1.20 \\
\hline & & AG167\# & 14.07 & 24.63 & 9.69 & 1.852 & 0.547 & 1.557 & 1.065 & 0.489 & 0.375 & 0.058 & 22.72 & 54.34 & 1.00 \\
\hline & & AG $166^{*}$ & 21.14 & 36.88 & 14.02 & 2.51 & 0.82 & 1.76 & 1.02 & 0.61 & 0.51 & 0.09 & 25.12 & 79.36 & 1.20 \\
\hline
\end{tabular}




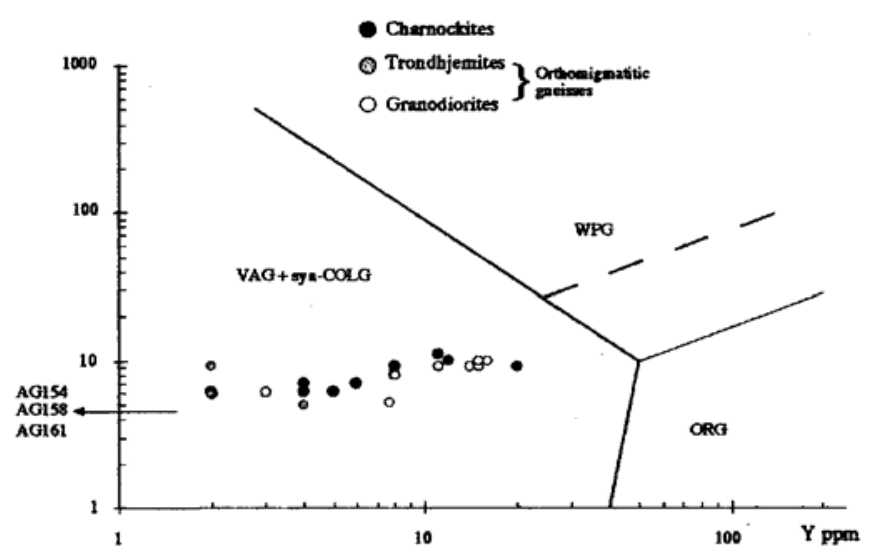

Figure 3 - Chemical composition of the Amsaga orthogneisses plotted in a geotectonic Y vs. Nb diagram (Pearce etal. 1984). Figura 3 - Composição química dos ortognaisses de Amsaga reportada num diagrama geotectônico Y vs. Nb (Pearce et al. 1984).

O Granodiorites -> ${ }^{\text {gnri, ses }}$

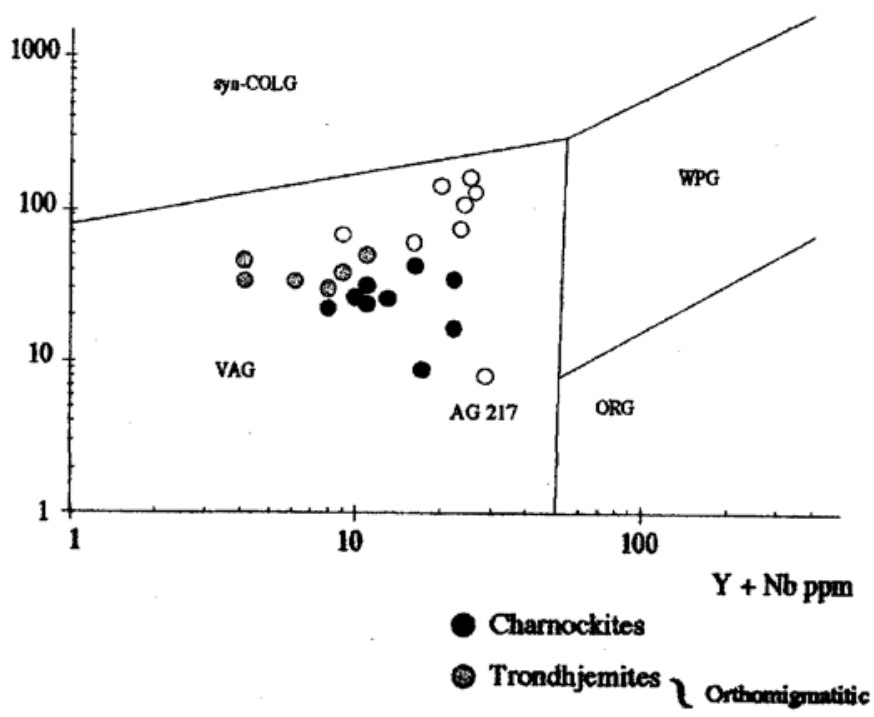

Figure 4 - Chemical composition of the Amsaga orthogneisses plotted in a geotectonic $Y+N b$ vs. Rb diagram (Pearce et al. 1984).

Figura 4 - Composição química dos ortognaisses de Amsaga reportada num diagrama geotectônico $\mathrm{Y}+\mathrm{Nb}$ vs. $\mathrm{Rb}$ (Pearce et al. 1984).

tion of plagioclase and apatite during the differentiation processes. This is in agreement with their increasing in REE contents and Eu negative anomaly with increasing of SÍÜ2. This differentiation process does not seem to exist in the Charnockites and Tdj. The other anomalies observed in the spidergrams could be linked to the metamorphic processes. At least two kinds of metamorphic processes have been documented in the area: the first is the granulitic event which affected the entire area and the second is hydrothermal meta-
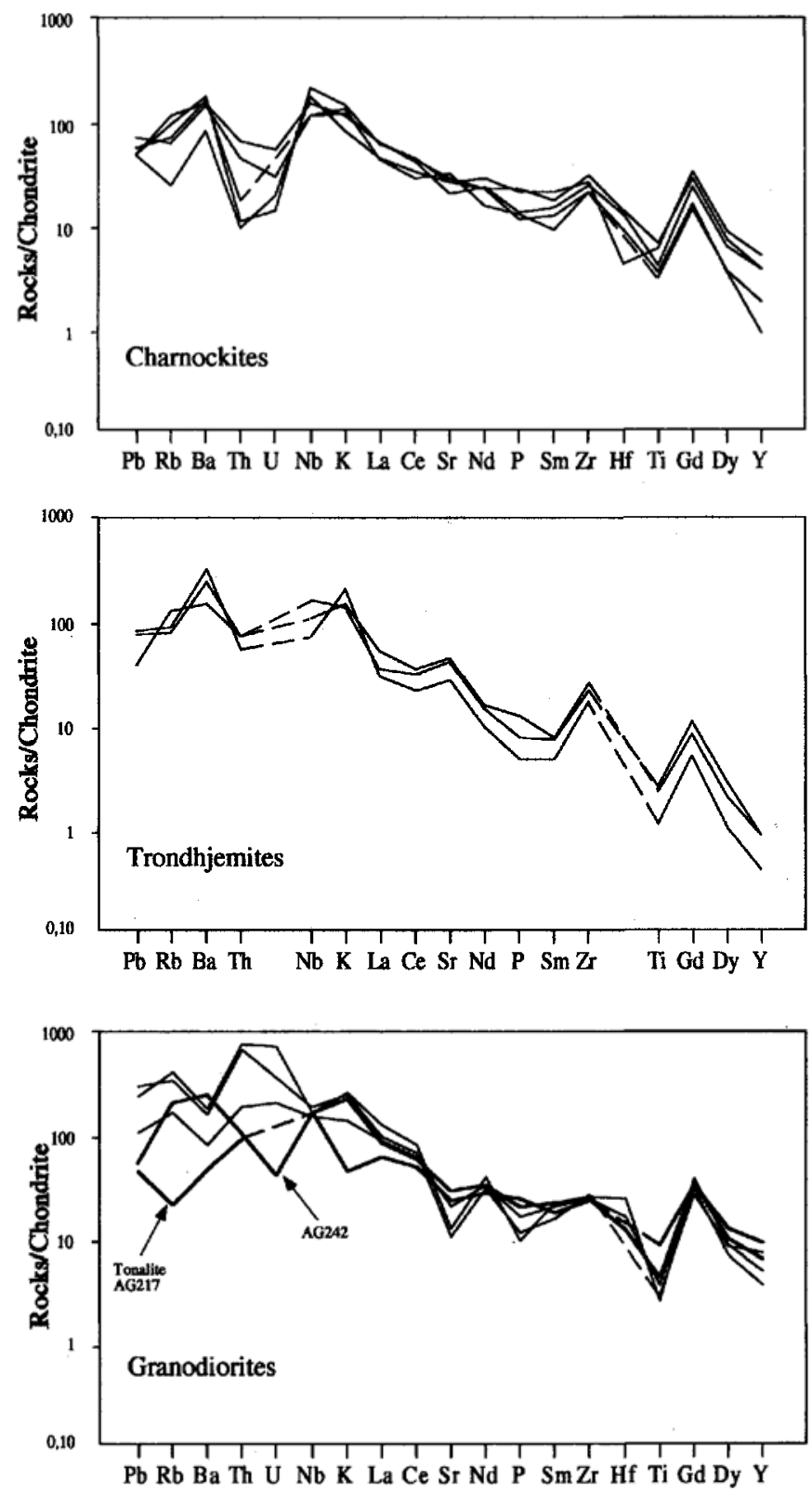

Figure 5 - Spidergrams of the Amsaga orthogneisses normalized against chondrites (Sun 1982; except Gd and Dy: Nakamura 1974, andtif, Wood et al 1979). Figura 5 - Spidergramas dos ortognaisses do Amsaga normalizados ao condrito (Sun 1982; para o Gd e Dy: Nakamura 1974 e para o Hf: wood et al. 1979).

morphism, essentially observed along the vertical mylonite zones. The latter seems to have affected the migmatitic orthogneisses but not the charnockitic body of S nine Kembo (Potrel 1994). The depletion in Rb, K and essentially Th and $\mathrm{U}$ of the charnockite and Tdj might be due to the granulitic event, as this behavior is common in high grade terrains (eg. Tarney \& Windley 1977, Weaver et al. 1978). The fact that the $\mathrm{K} / \mathrm{Rb}$ ratios of the samples remain lower than the classical depleted granulite ratio could be due to a similar depletion in $\mathrm{K}$ and $\mathrm{Rb}$, or by a renewal of the initial ratio during retrograde processes (Moorlock et al. 1972, Drury 1973, 1974). The 

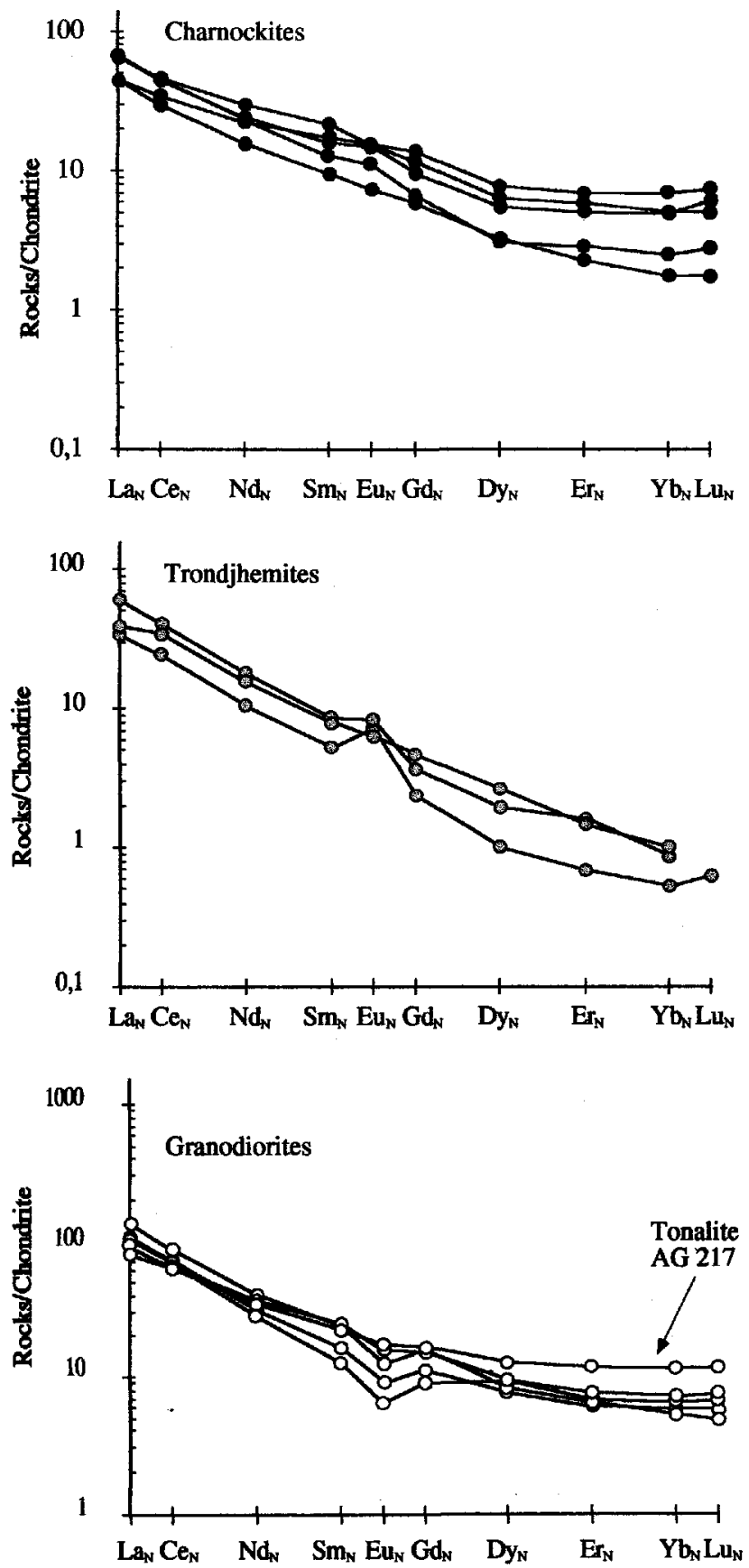

Figure 6 - Rare Earth element patterns of the Amsaga orthogneisses (chondritic normalisation of Taylor \& Gorton 1977).

Figura 6 - Padrões de Terras Raras dos ortognaisses do Amsaga (normalizados ao condrito segundo Taylor e Gorton 1997).

strong depletion in $\mathrm{Y}$ observed in the charnockite and Tdj samples (and particularly in the Tdj with some $\mathrm{Y}$ contents lower than $1 \mathrm{ppm}$ ) remains ambiguous as this element is generally thought to be immobile during metamorphism (eg. Rollingson 1993). The more or less developed depletion in $\mathrm{Rb}, \mathrm{K}$, Th and U observed in samples AG 217 and AG 242 could also be explained by the granulite facies metamorphism. The enrichment in $\mathrm{Rb}$ and $\mathrm{Th}$ and $\mathrm{U}$ observed in the others granodiorites is more ambiguous: this could be due to the Island Arc nature of the samples as these magmas are generaly enriched in these elements (eg. Gill 1981, Thomson et al.
1984) or possibly to the metamorphic processes. In this case two hypothesis are proposed: either the granodiorites formed a sink during the granulite metamorphism and hence display anomalies opposite to those observed in the charnockite and Tdj, nor their composition was more affected by the hydrothermal metamorphism. The crystallization during these low grade processes of white micas and secondary biotites could explain the enrichment in $\mathrm{Rb}$ and $\mathrm{Th}$ could be concentrated in secondary epidote and titanite. The depletion in $\mathrm{Sr}$ could result in this case both from the fractional crystallization processes and from the breakdown of plagioclase to form sericite.

The REE pattern of these gneisses (Fig. 6) confirm the presence of the three petrologic groups observed in the normative An-Ab-Or diagram (Fig. 2a). The Tdj show a typical Archean TTG pattern with high $(\mathrm{La} / \mathrm{Yb}) n$ ratio and positive Eu anomalies (eg. Condie 1981, Martin 1986, Condie 1992). The charnockite patterns are less characteristic but exhibit also the Archean TTG features. On the other hand, the granodiorite and the tonalitic sample AG 217 REE patterns are closer to the post-archean TTG, as they are less fractionated and exhibit significant negative Eu anomalies (eg. Condie 1992), even if they are clearly older than $2.7 \mathrm{Ga}$, as they are intruded by the Guelb el Azib and Iguilid gabbros (Auvray et al. 1992a, Potrel 1994, Potrel et al., submitted). The highly fractionated REE patterns of Archean TTG are interpreted as resulting from the presence of garnet and/or amphibole remaining in the residual solid after melting and segregation of these magmas (eg. Barker \& Arth 1976, Martin 1987, Drummond \& Defant 1990). Hence this feature is directly linked to the magmatic source of these gneisses and was not a result of fractional crystallization processes. Also, we could conclude that the differences observed in the REE patterns of the Amsaga orthogneisses indicate different sources, at least for the charnockite and Tdj on one side and granodiorites on the other side. This conclusion is in agreement with the scattering in the $\mathrm{Nd}$ model ages of these gneisses and their fairly parallel $\varepsilon \mathrm{Nd}$ versus time evolution lines (Potrel 1994, Potrel et al., submitted).

CONCLUSION This work represents the first geochemical data obtained from the Archean basement of the Reguibat Rise. These preliminary results do not allow proposal of detailed geodynamical and petrological model for this zone for the moment. Some features could nevertheless be distinguished. The Amsaga orthogneisses define a classical Archean calc-alkaline trend of trondjhemitic affinity and the primary composition of the magmas is in agreement with their Island Arc nature. The charnockites and Tdj chemical compositions indicate a depletion in $\mathrm{K}, \mathrm{Rb}$, Th and $\mathrm{U}$, probably linked to the high grade event. The REE patterns of the migmatitic orthogneisses indicate that they were derived from at least two distinct sources and are not homogeneous as was considered in previous studies (e.g. Barrère 1967, Auvray et al. 1992a et b, Bronner 1992). Further studies are required to establish the exact nature of these different magmas. Furthermore, the superposition of granulitic and hydrothermal events caused a strong perturbation of the primary composition of the samples and a detailed study is necessary to evaluate the precise mode of this chemical disturbance.

Acknowledgements Field expenses were supported by French-Mauritanian cooperation grant (IRIM). I would like to thank M. Lê Coz-Bouhnik, N. Morin, O. Hénin, J. Cornichet and J. Mace for their help in X-ray fluorescence and isotopic dilution analyses. I thank J.A. Barrat for the ICP-MS analyses. I thank Prof. T. Liverton and two anonymous reviewers for constructive criticism of the manuscript. 


\section{REFERENCES}

Auvray, B.; Peucat, J.J.; Potrel, A.; Burg, J.P.; Caruba, C.; Lo, K. 1992a. Données géochronologiques nouvelles sur 1'Archéen de 1'Amsaga (Dorsale Réguibat, Mauritanie). Comptes Rendues de 1'Acadadémie dês Sciences de Paris, 315 (II): 63-70.

Auvray, B.; Burg, J.P.; Caruba, C.; Dars, C.; Lo, K. 1992. 1'Amsaga (Mauritanie), fragment archéen du Craton Quest Africain: observations et hypotheses nouvelles. Journal of African Earth Sciences, 2:183-190.

Arth, J.G.; Hanson, G.N. 1975. Geochemistry and origin of the early Precambrian crust of Northeastern Minnesota. Geochimica et Cosmochimica Acta, 39: 325-362.

Barker, F; Harth, J.G. 1976. Generation of trondhjemitic -tonalitic liquids and Archean bimodal trondhjemite - basalt suites. Geology, 4: 596-600.

Barker, F. 1979. Trondhjemite s, dacites and related rocks. F. Barker ed., Amsterdam, Else vier: 414 p.

Bronner, G. 1992. Structure et evolution d' un craton archéen, la Dorsale Reguibat Occidentale (Mauritanie) tectonique et métallogenie des formations ferrifères. These d'etat Université de Marseille. $448 \mathrm{p}$

Collerson, K.D.; Bridgewater, D. 1979. Metamorphic development of early Archean tonalitic and trondhjemitic gneisses: Saglek area, Labrador. In: Barker, F. ed. Trondhjemites, Dacites and related rocks. Amsterdam, Elsevier. p. 205-273.

Condie, K.C. 1981. Archean greenstone belts, ed. Windley, B .F., Amsterdam, Elsevier. $434 \mathrm{p}$

Condie, K.C. 1992. Chemical composition and evolution of the upper continental crust: contrasting results from surface samples and shales. In: 29th International Geophysical Congress, Kyoto, 1992.

Drummond, M.S.; Defant, M.J. 1990. A model for trondhjemite-tonalite-dacite genesis and crustal growth via slab melting: Archean to modern comparisons. Journal of Geophysical research, 95:21503-521.

Drury, S.A. 1973. The geochemistry of Precambrian granulite facies rocks from the Lewisian complex of Tiree, Inner Hebrides, Scotland. Chemical Geology, 11: 167-188.

Drury, S.A. 1974. Chemical changes during retrogressive metamorphism of Lewisian granulite facies rocks from Coll and Tiree, Scotland. Journal of Geology, 10: 237-256.

Gill, J. 1981. Orogenic Andesites and plate tectonics, ed. Berlin, Heildelberg, New York, Springer Verlag. 390p.

Heier, K.S. 1973. Geochemistry of granulite facies rocks and problems of their origin. Royal Society of London Philosophical Transaction, 273: 429-442.

Martin, H. 1986. Effect of steeper Archean geothermal gradient on geochemistry of subduction-zone magmas. Geology, 14: 753-756.

Moorlock, B.S.P.; Tarney, J.; Wright, A. E. 1972. K-Rb ratios of intrusive anorthosite veins from Angmagssalik, East Greenland. Earth and Planetary Sciences Letters, 14: 39-46.

Nakamura, N. 1974. Determination of REE, Ba, Fe, Mg, $\mathrm{Na}$ and $\mathrm{K}$ in carbonaceous and ordinary chondrites. Geochimica et Cosmochimica Acta, 38: 757-775.
O'Connor, J.T. 1965. A classification for quartz-rich igneous rocks based on feldspar ratio. U.S. Geological Survey Prof. Paper, 525-B: 79-84.

Pearce, J.A.; W. Harris, N.B.; Tindle, N.B. 1984. Trace element discrimination diagrams for the tectonic interpretation of granitic rocks. Journal of Petrology, 25: 956-983.

Potrel, A. 1994., Evolution tectono-métamorphique d'un segment de croüte continentale archéenne. Exemple de l'Amsaga (R.I. Mauritanie), Dorsale Réguibat (craton Quest Africain)., These d'Universite, Université de Rennes I, Mémoire de Géosciences Rennes, 56, 400 p.

Potrel, A.; Peucat, J.J.; Fanning, C.M.; Auvray, B.; Burg, J.P.; Caruba, C. 1996. 3.5 Ga old terranes in the West African Craton, Mauritania. Journal of the Geological Society of London, 153: 507-510.

Potrel, A; Peucat, J.J.; Fanning, C.M. Submitted to Precambrian Research, Chronological evolution of the Amsaga area (Reguibat Rise, West African Craton).

Rollinson, H. 1993. Using geochemical data: evaluation presentation, interpretation, ed. Longman Group UK Ltd, 352 p.

Sun, S.S. 1982. Chemical composition and origin of the Earth's primitive mantle. Geochimica et Cosmochimica Acta, 46: 179-192..

Tarney, J.; Windley, B.F. 1977. Chemistry, thermal gradients and evolution of the lower continental crust. Journal of the Geological Society of London, 134: 153-172.

Tarney, J.; Weaver, B.L.; Drury, S.A. 1979. Geochemistry of Archean trondhjemitic and tonalitic gneisses from Scotland and E Greenland, In: Barker, F. ed. Trondhjemites, Dacites and related rocks. Amsterdam, Elsevier. p. 275-299.

Taylor, S.R.; Gorton, M.P. 1977. Geochemical application of spark source mass spectrography-III. Element sensitivity, precision and accuracy. Geochimica et Cosmochimica Acta, 41: 1375-1380.

Thompson, R.N.; Morrison, M.A.; Hendry, G.L.; Parry, S.J. 1984. An assessment of relative roles of crust and mantle in magma genesis: an elemental approach. Royal Society of London Philosophical Transaction, 310: 549-590.

Weaver, B.L.; Tarney, J.; Windley, B.F.; Saguvanam, E.B; Venkata Rao, V. 1978. Madras granulites: Geochemistry and P-T conditions of crystallisation. In: Windley, B.F. and Naqvi, S.M. ed. Archean Geochemistry. Amsterdam, Elsevier. p. 177-204.

Windley, B.F. 1986, The evolving continents, ed. John Wiley \& Sons, Chichester, $399 \mathrm{p}$

Wood, D.A.; Tarney, J.; Varet, J.; Saunders, A.D.; Bougault, H.; Joron, J.L.; Treuil, M.; Cann, J.R. 1979. Geochemistry of basalts drilled in the North Atlantic by IPOD Leg 49: implications for mantle heterogeneity. Earth and Planetary Sciences Letters, 42: 77-97.

MANUSCRITO A924

Recebido em 01 de julho de 1997 Revisão do autor em 01 de setembro de 1997 Revisão aceita em 03 de setembro de 1997 